\title{
Growth retardation and congenital heart disease in a boy with a ring chromosome 6 of maternal origin
}

\author{
Yanling Dong, Jian Li, Ziye Zeng, Xue Zhang, Mingxin Liang, Hong Yi, Jianyun Luo and Junnan Li
}

\begin{abstract}
Background: Rare chromosomal structural abnormalities, including ring chromosomes, often pose challenges to clinical genetic counselling.

Results: Here, we report a newborn with congenital heart disease and developmental delay who inherited ring chromosome $6[46, X Y, r(6)(p 25 q 27) m a t]$ from a phenotypically normal mother. Genotypes and phenotypes were analysed by molecular cytogenetic analysis, whole-exome sequencing and literature review.

Conclusions: Our study showed that the pathogenicity of the ring chromosome abnormality [r(6)(p25q27)] was mainly affected by chromosome imbalance, deletions of genes with haploinsufficiency, duplications of genes with triple sensitivity, parental inheritance of the imbalance and the imprinting status of the affected genes.
\end{abstract}

Keywords: Ring chromosome 6 (RC6), SNP array, Prenatal diagnosis

\section{Background}

Ring chromosomes (RC) are a specific chromosomal abnormalities, being rare genetic events caused by terminal deletions and an intrachromosomal fusion [1]. RCs were first discovered in tumour cells in 1956 [2] and later in other autosomal and sex chromosomes in clinical cases [3-7]. To date, all 23 human chromosomes have been reported to be involved in RC-formation, with an overall incidence between $1 / 30,000$ and 1/60,000 [8]. Two main types of RCs have been described: (1) 46,XN,r, where normal linear homologues are replaced by fulllength rings or unbalanced rings [8]; and (2) $47, \mathrm{XN},+\mathrm{r}$, where the RC is supernumerary. In both cases, RC-carrying cell lines may coexist with normal cell lines in the mosaic state.

*Correspondence: summerbolo@163.com

Department of Obstetrics and Gynecology, The First Affiliated Hospital

of Chongqing Medical University, No. 1, Youyi Road, Yuanjiagang,

Yuzhong District, Chongqing 400016, People's Republic of China
At the time of publication of this article, there have been few reports about RCs derived from chromosome 6 [9]; inheritance from a parent was not reported yet.

Here, genome-wide copy number and pedigree analysis were performed on a foetus-to-newborn case by banding cytogenetics and molecular genetics, and a hereditary RC6 abnormality was identified [r(6)(p25q27)]. Clinical consequences and implications for genetic counselling are discussed here.

\section{Case report}

A 23-year-old pregnant woman, G1P0 (gravida 1, para 0 ), was admitted to foetal medical centre. The pregnant woman was $142 \mathrm{~cm}$ tall, within weight in the normal range for height, as were her parents and husband. The couple had normal intellectual development and no abnormal family history or mutagenic exposures.

This pregnancy was conceived naturally. No noninvasive prenatal genetic testing (NIPT) was performed in the first trimester of pregnancy. However, sonography at $24+$ weeks of gestation (w.o.g.) detected intrauterine original author(s) and the source, provide a link to the Creative Commons licence, and indicate if changes were made. The images or other third party material in this article are included in the article's Creative Commons licence, unless indicated otherwise in a credit line to the material. If material is not included in the article's Creative Commons licence and your intended use is not permitted by statutory regulation or exceeds the permitted use, you will need to obtain permission directly from the copyright holder. To view a copy of this licence, visit http://creativecommons.org/licenses/by/4.0/. The Creative Commons Public Domain Dedication waiver (http://creativeco mmons.org/publicdomain/zero/1.0/) applies to the data made available in this article, unless otherwise stated in a credit line to the data. 
growth retardation (IUGR), absence of nasal bone (Fig. 1A), and ventricular septum defect (Fig. 1B). Ultrasonography at $30^{\text {th }}$ w.o.g. confirmed the previous findings and additionally a foramen ovale. However, at 34 w.o.g. a second ultrasound examination revealed no abnormalities at all.

Cytogenetic analysis (G-banding resolution was approximately 400-550 bands) and chromosomal microarray (CMA) were done after amniocentesis in $24+$ w.o.g.. Also maternal blood sample and that of parents of the mother were cytogenetically analysed. After birth, karyotype and CMA analyses were performed again. Pre- and postnatal banding cytogenetics showed a karyotype of 46,XY,r(6)(p25q27)mat. The mother had in peripheral blood a mosaic karyotype: 46,XX,r(6) (p25q27) [44]/47,XX,r(6)(p25q27), +r (6)(p25q27) [2]/46, $\mathrm{XX}[15]$, and the father had a normal result as 46,XY (Fig. 2A-D). The karyotypes of the maternal grandmother and grandfather were normal (46,XX; $46, \mathrm{XY})$.
For CMA a SNP array was performed using KaryoStudio 1.4.3.0 Build 37 software (Illumina, San Diego, CA) to define possible copy number changes. Besides wholeexome sequencing (WES) was completed by the BGI Huada Gene Shenzhen Huada Clinical Testing Centre as previously reported [9]. Obtained molecular genetic data was bioinformatically analysed using DECIPHER (http://decip her.sanger.ac.uk), UCSC (http://genome.ucsc.edu), DGV (http://dgv.tcag.ca/dgv/app/home), ClinGen (http://dosage. clinicalgenome.org/), gene imprint database (http://www. geneimprint.com) and other Online-Mendelian Inheritance in Man (OMIM) databases (http://www.omim.org). Karyotype and CMA-results are described according to the International System for Human Cytogenomic Nomenclature (ISCN, 2020) [10].

CMA analyses in the foetus (amnion and peripheral blood) gave the following result: $\operatorname{arr}[\mathrm{GRCH} 37] 6 \mathrm{p} 25.3(203$, 254_1,138,134) ×1,6p25.3p25.2(1,153,042_4,172,096) $\times 3$ (Fig. 2E). In the mother the CMA-findings were: arr [GRCH37]6p25.3(203,254_1,138,134) × 1 2,6p25.
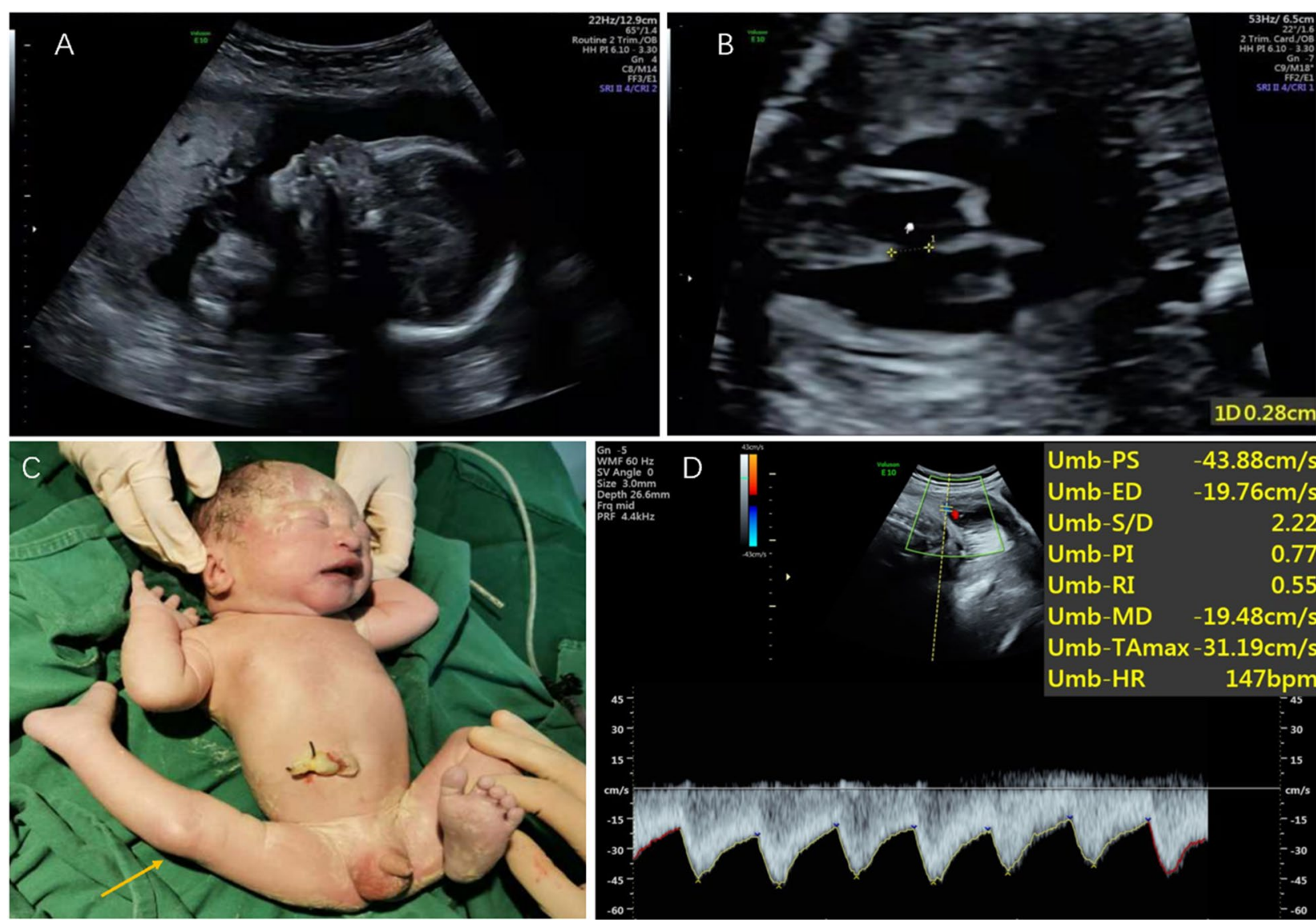

Fig. 1 Foetal ultrasound at 24 weeks and abnormal newborn detections: absence of nasal bone (A) and ventricular septal defect (B). The right knee joint of the newborn was dislocated (C). Colour ultrasound indicated congenital heart malformation: ventricular septal defect; atrial septal defect (muscle) (D) 


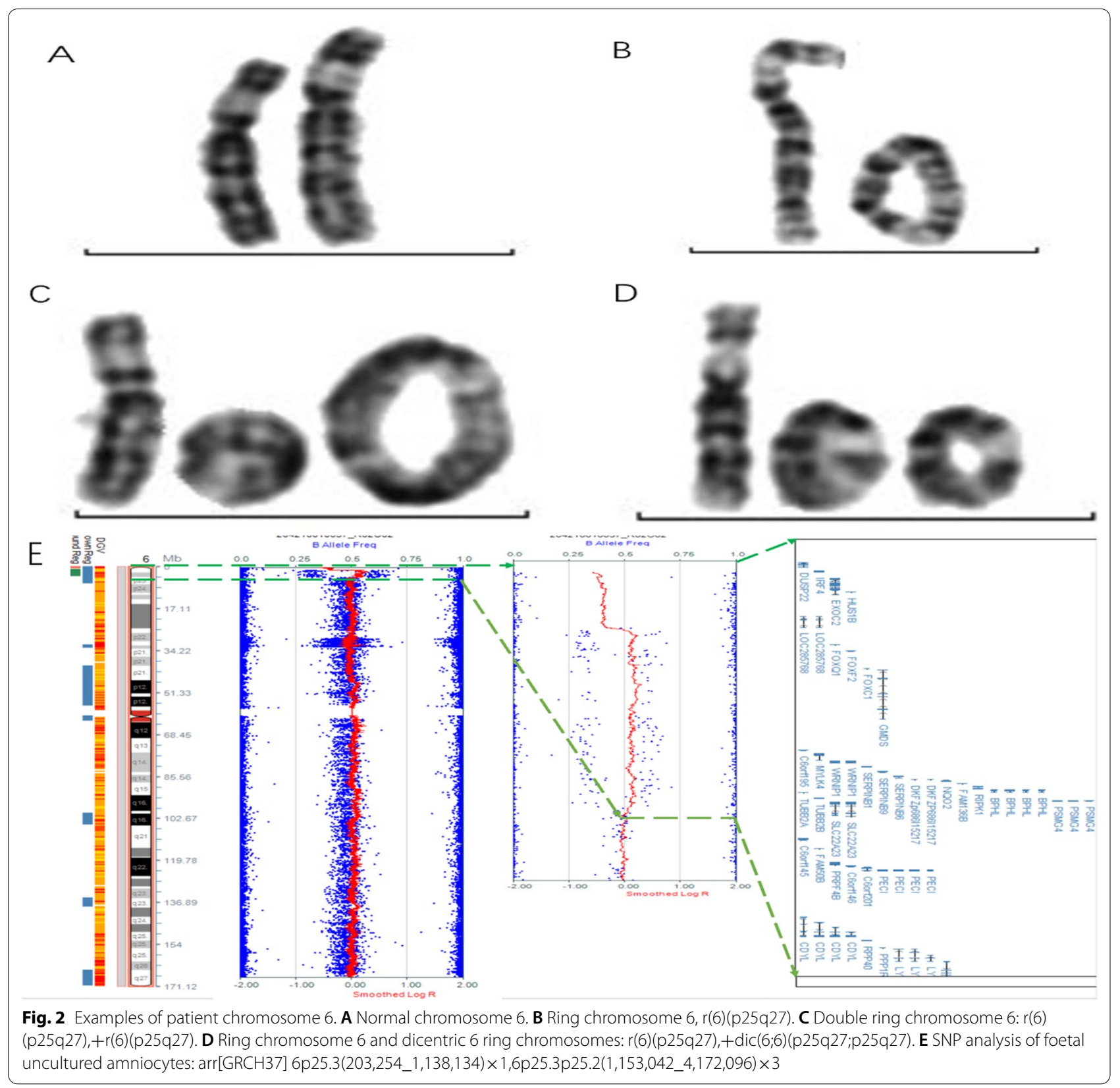

3p25.2(1,153,042_4,172,096) $\times 2 \sim 3$. SNP-array confirmed the mosaic situation of $90 \%$ of the cells carrying the ring chromosome; also a isoUPD(6) mosaicism was found for $10 \%$ of the cells, explaining the 15 cells with normal karyotype 46,XX found in cytogenetics as being due to monosomic rescue.

Whole-exome sequencing confirmed the result of SNP-array as: seq[GRCh37] dup(6)(p25.3p25.2) chr6:g.1127408_4191151dup (3.06 Mb) and seq[GRCh37] del(6)(p25.3p25.3) chr6:g.63810_1127408del (1.06 Mb).
The boy was delivered by caesarean section at $39^{+2}$ weeks of gestation. Congenital dislocation of the right knee joint occurred in the newborn (Fig. 1C), even though no knee joint abnormality was observed at any stage of pregnancy. After treatment, the dislocation of the knee and limb was normal. The newborn had a birth weight too low for gestational age of $2.150 \mathrm{~kg}$, and was overall in good mental condition, without any inborn defects. However, follow-up 8 months of age showed developmental delay concerning length $(64 \mathrm{~cm})$ and weight $(5 \mathrm{~kg})$; also congenital heart malformation was 
diagnosed by Doppler sonography as ventricular septal defect and atrial septal defect with the enlarged diameter of pulmonary artery and left heart enlargement; also the third top valve had a micro reflux and pulmonary hypertension was detected while left ventricular systolic function was normal (Fig. 1D).

Overall, as of the date of publication of this article, there have been no abnormal phenotypes in the newborn except for growth retardation and congenital heart malformations.

\section{Discussion}

Here we report the first case of a maternally inherited RC6 r(6)(p25q27) without major clinical consequences. Yet, 9 cases have been reported in the literature with comparable de novo $\mathrm{r}(6)(\mathrm{p} 25 \mathrm{q} 27)$, diagnosed between 2 and 13 years old. After 2013, molecular technology was applied to determine the breakpoint; for ring chromosome 6 with $6 \mathrm{p} 25$ to $6 \mathrm{q} 27$, all cases reported in the literature apart from the present one (Table 1) are de novo. Most patients have clinical features, including dysmorphic face, mental retardation, cerebellar malformation, delayed development, and cardiac abnormalities. The details of the genes involved in the chromosomal imbalance region [46,XY,r $(6)(\mathrm{p} 25 \mathrm{q} 27)]$ are shown in Table 2 and indicate that most of these genes are OMIM genes, such as DUSP22, IRF4, and FOXC1. There are currently two imprinted genes located on chromosome 6p25 (Table 2): FAM5OB and PXDC1. Both genes were paternally expressed. Even though UPD(6) was detected in $10 \%$ of the blood cells of the mother of the patient, a clinical effect is not likely due to that postzygotic rescue phenomenon.

$\mathrm{RC}$ formation mechanisms may include the loss and/ or acquisition of genetic material. Previous studies have shown that at least three mechanisms may lead to RCs: inv dup del rearrangements, double-strand breaks and telomeric junctions [11]. RCs are generally considered to be the result of chromosomal aberrations during meiosis or in early postzygotic phase. Two open ends are connected to form a continuous ring. This mechanism assumes that some genetic material may be lost during ring formation. Also RCs tend to be lost during mitoses and cells with $45, \mathrm{XN},-6$ are not viable. This is the reason for IUGR observed in the patient and his mother.

Table 1 Cases reported in the literature with r(6)(p25q27)

\begin{tabular}{|c|c|c|c|c|c|c|}
\hline Year & PMID & Karyotype & $\begin{array}{l}\text { Molecular } \\
\text { technology }\end{array}$ & Parental karyotype & $\begin{array}{l}\text { Duration of } \\
\text { follow-up }\end{array}$ & Clinical phenotype \\
\hline 1990 & 2333874 & $46, X X, r(6)(p 25 q 27) / 46, X X$ & not apply & Normal & Born-13 years old & $\begin{array}{l}\text { Facial abnormalities, } \\
\text { mental retardation, } \\
\text { epilepsy }\end{array}$ \\
\hline 1996 & 8905901 & $\begin{array}{l}46, X X, r(6)(p 25 q 27) / 45, X Y_{,-} \\
6 / 45, X Y,-6,+f\end{array}$ & not apply & $\begin{array}{l}\text { The mother was nor- } \\
\text { mal and the father not } \\
\text { provide it }\end{array}$ & Prenatal-17 months & $\begin{array}{l}\text { Hydrocephalus, global } \\
\text { retardation }\end{array}$ \\
\hline 2001 & 11223855 & $\begin{array}{l}46, X Y, r(6) \\
(p 25 q 27) / 46, X Y, \operatorname{dic} r(6 ; 6) \\
(p 25 q 27 ; p 25 q 27) / 45, X Y,-6\end{array}$ & not apply & $\begin{array}{l}\text { The father was normal } \\
\text { and in mother there } \\
\text { was a Robertsonian } \\
\text { translocation }\end{array}$ & Born-11 years old & Aortic root dilatation \\
\hline 2013 & 23398904 & $46, X Y, r(6)(p 25 q 27)$ & $\mathrm{FISH}+\mathrm{CMA}$ & Not provided & sixteen months old & $\begin{array}{l}\text { Growth disorders, heart } \\
\text { disease, facial abnormali- } \\
\text { ties }\end{array}$ \\
\hline 2015 & 26213576 & $\begin{array}{l}46, X X, r(6) \\
(\text { p25q27)/46,XX,dic r(6;6) } \\
(\text { p25q27;p25q27)/45,XX,-6 }\end{array}$ & CMA & Not provided & 3 years old & $\begin{array}{l}\text { Periventricular ectopia } \\
\text { and white matter abnor- } \\
\text { malities }\end{array}$ \\
\hline 2018 & 30305128 & $\begin{array}{l}46, X Y, r(6) \\
\text { (p25.3q27)/46,XY,dic r(6;6) } \\
\text { (p25.3q27;p25.3q27)/45,XY,-6 }\end{array}$ & $\mathrm{FISH}+\mathrm{CMA}$ & Normal & 11 years old & $\begin{array}{l}\text { Stunting, mental retarda- } \\
\text { tion, microcephaly }\end{array}$ \\
\hline 2018 & 29656294 & $\begin{array}{l}46, X Y, r(6) \\
(p 25 q 27) / 46, X Y, \operatorname{dic} r(6 ; 6) \\
(p 25 q 27 ; p 25 q 27) / 45, X Y,-6\end{array}$ & $\mathrm{FISH}+\mathrm{CMA}$ & Normal & 12 years old & $\begin{array}{l}\text { Abnormal facial appear- } \\
\text { ance, stunting, hetero- } \\
\text { topic gray matter }\end{array}$ \\
\hline 2018 & 30225942 & $46, X Y, r(6)(p 25.3 q 27)$ & $M L P A+C M A$ & Not provided & Prenatal-2 years old & $\begin{array}{l}\text { Anterior segment } \\
\text { dysplasia and cardiac } \\
\text { abnormalities }\end{array}$ \\
\hline 2021 & 8504673 & $46, X X, r(6)(p 25 q 27)$ & CMA & Normal & 10 years old & $\begin{array}{l}\text { Microcephaly, Abnormal } \\
\text { facial appearance, hyper- } \\
\text { telorism, and cardiac } \\
\text { abnormalities }\end{array}$ \\
\hline
\end{tabular}


Table 2 Genes present in the 6p25.3 deleted region and 6p25.3p25.2 duplicated region

\begin{tabular}{|c|c|c|c|c|c|c|}
\hline Gene & Description & Gene type & $\% \mathrm{HI}$ & Imprinting status & Known syndromes/diseases & ID of OMIM \\
\hline \multicolumn{7}{|c|}{ Genes present in the $6 \mathrm{p} 25.3$ deleted region } \\
\hline DUSP22 & dual specificity phosphatase 22 & PC & 38.68 & NA & NA & 616778 \\
\hline IRF4 & interferon regulatory factor 4 & PC & 19.27 & NA & $\begin{array}{l}\text { Skin/hair/eye pigmentation, variation } \\
\text { in, } 8\end{array}$ & 601900 \\
\hline EXOC2 & exocyst complex component 2 & PC & 34.26 & NA & NA & 615329 \\
\hline HUSTB & HUS1 checkpoint clamp component B & PC & 97.37 & NA & NA & 609713 \\
\hline \multicolumn{7}{|c|}{ Genes present in the $6 \mathrm{p} 25.3 \mathrm{p} 25.2$ duplicated region } \\
\hline BPHL & biphenyl hydrolase like & PC & 69.92 & NA & NA & 616778 \\
\hline LINC01600 & $\begin{array}{l}\text { long intergenic non-protein coding } \\
\text { RNA } 1600\end{array}$ & ncRNA & 99.38 & NA & NA & NA \\
\hline C6orf201 & chromosome 6 open reading frame 201 & PC & 90.99 & NA & NA & NA \\
\hline$E C 12$ & enoyl-CoA delta isomerase 2 & PC & 64.53 & NA & NA & 608024 \\
\hline FAM217A & $\begin{array}{l}\text { family with sequence similarity } 217 \\
\text { member A }\end{array}$ & PC & 71.39 & NA & NA & NA \\
\hline FAM50B & $\begin{array}{l}\text { family with sequence similarity } 50 \\
\text { member B }\end{array}$ & PC & 73.35 & Imprinted (Paternal) & NA & 614686 \\
\hline FOXC1 & forkhead box C1 & PC & 9.01 & NA & $\begin{array}{l}\text { Anterior segment dysgenesis } 3 \\
\text { multiple subtypes, AD; Axenfeld-Rieger } \\
\text { syndrome, type 3, AD }\end{array}$ & 601090 \\
\hline FOXF2 & forkhead box F2 & PC & 29.64 & NA & NA & 603250 \\
\hline FOXQ1 & forkhead box Q1 & PC & 74.58 & NA & NA & 612788 \\
\hline GMDS & GDP-mannose 4,6-dehydratase & PC & 3.84 & NA & NA & 602884 \\
\hline MYLK4 & $\begin{array}{l}\text { myosin light chain kinase family } \\
\text { member } 4\end{array}$ & PC & 57.67 & NA & NA & NA \\
\hline NQO2 & $\begin{array}{l}\text { N-ribosyldihydronicotinamide: quinone } \\
\text { reductase } 2\end{array}$ & PC & 69.72 & NA & Breast cancer susceptibility & 160998 \\
\hline PRPFAB & pre-mRNA processing factor $4 \mathrm{~B}$ & PC & 3.38 & NA & NA & 602338 \\
\hline PSMG4 & proteasome assembly chaperone 4 & PC & 70.84 & NA & NA & 617550 \\
\hline PXDC1 & PX domain containing 1 & PC & 64.96 & Imprinted (Paternal) & NA & NA \\
\hline RIPK1 & $\begin{array}{l}\text { receptor interacting serine/threonine } \\
\text { kinase } 1\end{array}$ & PC & 52.24 & NA & $\begin{array}{l}\text { Autoinflammation with episodic fever } \\
\text { and lymphadenopathy, AD; }\end{array}$ & 603453 \\
\hline SERPINB1 & serpin family B member 1 & PC & 35.07 & NA & $\begin{array}{l}\text { Immunodeficiency } 57 \text { with autoinflam- } \\
\text { mation, AR }\end{array}$ & 130135 \\
\hline SERPINB6 & serpin family B member 6 & PC & 69 & NA & NA & 173321 \\
\hline SERPINB9 & serpin family B member 9 & PC & 88.04 & NA & ?Deafness, autosomal recessive 91,AR & 601799 \\
\hline$S L C 22 A 23$ & solute carrier family 22-member 23 & PC & 50.77 & NA & NA & 611697 \\
\hline TUBB2A & tubulin beta 2A class Ila & PC & 20.26 & NA & NA & 615101 \\
\hline TUBB2B & tubulin beta 2B class IIb & PC & 24.97 & NA & $\begin{array}{l}\text { Cortical dysplasia, complex, with other } \\
\text { brain malformations } 5, A D\end{array}$ & 612850 \\
\hline WRNIP1 & WRN helicase interacting protein 1 & PC & 36.94 & NA & $\begin{array}{l}\text { Cortical dysplasia, complex, with other } \\
\text { brain malformations } 7, A D\end{array}$ & 608196 \\
\hline
\end{tabular}

$A D$ autosomal dominant; $A R$ autosomal recessive; \%HI DECIPHER Haploinsufficiency index (High ranks (e.g. 0-10\%) indicate a gene is more likely to exhibit haploinsufficiency, low ranks (e.g. 90-100\%) indicate a gene is more likely to NOT exhibit haploinsufficiency). PC protein-coding gene. ncRNA non-coding RNA. NA not accessible. OMIM (https://omim.org/): Online Mendelian Inheritance in Man ${ }^{\circledR}$. ClinGen Haploinsufficiency Score: score of haploinsufficient (deletion) or triplosensitive (duplication) (https://dosage.clinicalgenome.org/)

In conclusion, we reported the first case of a foetus with $\mathrm{r}(6)(\mathrm{p} 25 \mathrm{q} 27) \cdot \operatorname{arr}[\mathrm{GRCH} 37] 6 \mathrm{p} 25.3\left(203,254 \_1,138,1\right.$ $34) \times 1,6 \mathrm{p} 25.3 \mathrm{p} 25.2\left(1,153,042 \_4,172,096\right) \times 3 \quad$ originating from the mother. Although other genetic effects on the congenital abnormity of the foetus cannot be excluded, the pathogenicity is mainly due to loss of RC6 during mitoses, leading to growth restrictions. Also influence of terminal deletion and duplication in chromosome 6 on heart phenotype cannot be excluded.

\section{Abbreviations}

CMA: Chromosomal microarray analysis; FGR: Foetal growth restriction; HGMD: Human Gene Mutation Database; RCs: Ring chromosomes; SNPs: Single-nucleotide polymorphisms; SNVs: Allele-nucleotide variants; WES: Whole-exome sequencing. 


\section{Acknowledgements}

We are grateful for the participation of the family in this study.

\section{Authors' contributions}

Y.D. wrote the main manuscript text. J.L. designed the study. J.L. performed the experiments. X.Z. performed statistical analysis. Z.Z., M.L. and H.Y. prepared Figs. 1 and 2, and J.L. prepared Tables 1 and 2. All authors read and approved the final manuscript.

\section{Funding}

Not applicable.

\section{Availability of data and materials}

The datasets used and/or analysed during the current study are available from the corresponding author on request.

\section{Declarations}

\section{Ethics approval and consent to participate}

The experiments with ethics considerations were approved by The First Affiliated Hospital of Chongqing Medical University (licence number: 2021-263).

\section{Consent for publication}

Consent for publication had obtained from the family

\section{Competing interests}

The authors declare that they have no competing interests.

Received: 30 November 2021 Accepted: 9 February 2022

Published online: 05 March 2022

\section{References}

1. Peron A, Catusi I, Recalcati MP, Calzari L, Larizza L, Vignoli A, Canevini MP. Ring chromosome 20 syndrome: genetics, clinical characteristics, and overlapping phenotypes. Front Neurol. 2020;11:613035.

2. Levan A. Chromosome studies on some human tumors and tissues of normal origin, grown in vivo and in vitro at the Sloan-Kettering Institute. Cancer. 1956;9:648-63.

3. Chai H, Ji W, Wen J, DiAdamo A, Grommisch B, Hu Q, Szekely AM, Li P. Ring chromosome formation by intra-strand repairing of subtelomeric double stand breaks and clinico-cytogenomic correlations for ring chromosome 9. Am J Med Genet A. 2020;182:3023-8.

4. Huang $T$, Zhu L, Zhang SF, Hu XY, Cheng P, Luan SQ, Chen GH. A rare case of ring chromosome 3 syndrome. J Biol Regul Homeost Agents. 2020;34:2020.

5. Nozawa A, Ozeki M, Yasue S, Endo S, Kadowaki T, Ohnishi H, Muramatsu H, Hama A, Takahashi Y, Kojima S, Fukao T. Myelodysplastic syndromes in a pediatric patient with Cri du Chat syndrome with a ring chromosome 5. Int J Hematol. 2020;112:728-33.

6. Varas-Meis E, Delgado-Vicente S, Fernandez-Canga P, Rodriguez Prieto MA. Blaschkoid hypermelanosis in a patient with ring 18 chromosome. Inidan J Dermatol Venereol Leprol. 2020;86:316-8.

7. Myers KA, Bennett MF, Hildebrand MS, Coleman MJ, Zhou G, Hollingsworth G, Cairns A, Riney K, Berkovic SF, Bahlo M, Scheffer IE. Transcriptome analysis of a ring chromosome 20 patient cohort. Epilepsia. 2021;62:e22-8.

8. Kosztolanyi G. The genetics and clinical characteristics of constitutional ring chromosomes. J Assoc Genet Technol. 2009;35:44-8.

9. Wei X, Ju X, Yi X, Zhu Q, Qu N, Liu T, Chen Y, Jiang H, Yang G, Zhen R, Lan Z, Qi M, Wang J, Yang Y, Chu Y, Li X, Guang Y, Huang J. Identification of sequence variants in genetic disease-causing genes using targeted nextgeneration sequencing. PLoS ONE. 2011;6:e29500.

10. International Standing Committee on Human Cytogenomic Nomenclature, McGowan-Jordan J, Hastings RJ, Moore S. ISCN 2020: an international system for human cytogenomic nomenclature (2020). Basel: Hartford: 2020. p. 2020.

11. Pristyazhnyuk IE, Menzorov AG. Ring chromosomes: from formation to clinical potential. Protoplasma. 2018;255:439-49.

\section{Publisher's Note}

Springer Nature remains neutral with regard to jurisdictional claims in published maps and institutional affiliations.
Ready to submit your research? Choose BMC and benefit from

- fast, convenient online submission

- thorough peer review by experienced researchers in your field

- rapid publication on acceptance

- support for research data, including large and complex data types

- gold Open Access which fosters wider collaboration and increased citations

- maximum visibility for your research: over 100M website views per year

At BMC, research is always in progress.

Learn more biomedcentral.com/submissions 